\title{
UPAYA PENGELOLA DALAM MENINGKATKAN EKSISTENSI PERPUSTAKAAN BERBASIS IT DI DESA RENDE
}

\author{
Wenny Winarni \\ Yayasan Ar-Rosyd Assamad Rende \\ meiswenny@gmail.com
}

\begin{abstract}
ABSTRAK
Perpustakaan sebenarnya tidak hanya berfungsi sebagai tempat membaca saja, saat ini bahan pustaka tidak hanya Buku-buku, Majalah, Brosur tapi juga ada kumpulan DVD film motivasi, akses Internet dan ada Buku Digital. Fungsi perpustakaan juga bertambah tidak hanya sebagai sumber informasi tetapi juga sebagai sumber kegiatan yang bermanfaat untuk orang banyak. Sayangnya merubah citra fungsi perpustakaan tidaklah mudah dilakukan, agak sulit merubah kebiasaan serta cara pandang masyarakat mengenai image perpustakaan yang sudah cukup lama melekat, disini dibutuhkan Pustakawan yang mampu mengelola Perpustakaan sesuai fungsinya saat ini yaitu sebagai sumber kegiatan positif untuk masyarakat disekitar Perpustakaan berada sehingga masyarakat sekitar dapat merasakan impact dari adanya Perpustakaan. Pustakawan harus mampu melihat peluang dan potensi masyarakat yang belum berkembang dan belum berhasil guna, Pustakawan juga harus kreatif membuat suatu event yang dapat memfasilitasi antara informasi yang ada di Perpustakaan dengan apa yang dibutuhan oleh masyarakat. Pustakawan harus mampu menjadikan Pemustaka senang berada di Perpustakaan, merasa mudah mencari informasi baik dari buku ataupun internet sehingga berguna untuk dirinya sendiri maupun utuk orang lain.
\end{abstract}

Kata Kunci: Sumber informasi, Fungsi Perpustakaan, Pustakawan, Pemustaka, Peluang dan Potensi masyarakat yang belum berkembang.

\section{A. PENDAHULUAN}

Dalam Era modernisasi ini semua orang harus serba mengetahui akan segala hal yang terjadi di muka bumi ini agar tidak ketinggalan informasi dari orang ataupun negara lain, dan itu semua tidak harus didapat dengan melalui pendidikan formal melainkan bisa secara otodidak dengan banyak membaca atau melihat gambar. Saat ini masyarakat tahunya jenis bencana itu hanya yang disebabkan oleh alam, padahal dengan menurunnya minat baca pada kaum muda itu pun disebut bencana karena sama- sama akan mengakibatkan kesengsaraan, dengan musnahnya minat baca pada pemuda sebagai ujung tombak pengisi kemerdekaan Republik Indonesia, maka daerah-daerah yang tersebar di Indonesia akan mudah diadu domba karena kurangnya pengetahuan kaum muda baik pengetahuan khusus suatu ilmu ataupun pengetahuan umum yang telah atau sedang terjadi di Indonesia atau diseluruh dunia.

Untuk itu peran Perpustakaan sangatlah penting baik yang ada di lingkungan masyarakat, Taman Bacaan Masyarakat (TBM) ataupun perpustakaan yang ada di instansi dan lembaga kepemerintahan. Cara supaya Perpustakaan ramai dikunjungi pertama harus merubah citra perpustakaan yang biasanya hanya sebagai tempat 
menyimpan jejeran buku-buku, tidak boleh berisik dan hanya berfungsi untuk membaca saja dirubah menjadi perpustakaan yang mempunyai konsep yang sangat berbeda dengan zaman dahulu, bahan pustaka di perpustakaan saat ini bisa berbentuk DVD, dan Internet selain buku, majalah, koran, brosur yang biasanya ada sebagai bahan pustaka, perpustakaanpun beralih fungsi, tidak hanya sebagai tempat membaca melainkan menjadi sumber kegiatan bisa untuk pelatihan komputer, memasak, menulis, keterampilan dan sebagainya yang sifatnya positif.

Sesuai dengan Undang-Undang Republik Indobesia Nomor 43 Tahun 2007 tentang Perpustakaan dimana Presiden Republik Indonesia Menimbang:

a. Bahwa dalam mencerdaskan kehidupan bangsa sebagaimana diamanatkan dalam UUD 1945, perpustakaan sebagai wahana belajar sepanjang hayat mengembangkan potensi masyarakat dalam mendukung penyelenggaraan pendidikan nasional

b. Sebagai salah satu upaya untuk memajukan kebudayaan nasional

c. Bahwa dalam rangka meningkatkan kecerdasan kehidupan bangsa perlu ditumbuhkan gemar membaca melalui pengembangan dan pendayagunaan perpustakaan sebagai sumber informasi yang berupa karya tulis, cetak dan rekam.

\section{B. KAJIAN TEORI DAN METODE}

Penulis dalam melakukan penulisan hanya menggambarkan sutu proses kegiatan kerja atau menguraikan secara sistematis keadaan, kejadian-kejadian dan peristiwa yang ada di lapangan pada waktu melaksanakan praktek kerja menurut Nawawi Hadari dalam bukunya Metode Penelitian Sosial yaitu " Metode Deskriptif adalah sebagai prosedur pemecahan masalah yang diselidiki dengan menggambarkan atau melukiskan keadaan suatu subjek atau objek penelitian (seseorang, lembaga, masyarakat dan lain-lain) pada saat sekarang berdasarkan fakta-fakta yang tampak atau sebagaimana adanya. (Nawawi, 1995;63).

\section{Teknik Pengumpulan Data}

1. Studi Kepustakaan

Menurut Mochamad Nazir Studi Kepustakaan adalah: "Pengumpulan data dengan menelusuri literatur yang ada serta menelaahnya secara tekun". ( Nazir, Moh, Metode Penelitian, 1998:111). Dalam hal ini penulis mempelajari buku-buku dan peraturanperaturan yang ada yang berhubungan dengan Perpustakaan guna membntu penulis dalam menyelesaikan penulisan skripsinya.

\section{Studi Lapangan}

Menurut Mardalis Teknik Studi Lapangan adalah:" Pada hakekatnya merupakan metode untuk menemukan secara spesifik dan realis tentang apa yang terjadi pada suatu saat di tengah-tengah kehidupan masyarakat".(Mardalis, 1995:28)

Dalam Praktek Kerja penulis mengumpulkan data dengan melaksanakan penelitian langsung pada objek penelitian dengan cara-cara sebagai berikut :

\section{a. Observasi}

Menurut H. Hadari Nawawi dan H. M Martini Hadari, Observasi adalah " Teknik pengumpulan data dengan cara terjun langsung pada kegiatan atau pekerjaan yang dihadapi melalui pegamatan dan pencatatan sehingga diperoleh kebenaran data" 
(Nawawi , H. Hadaridan Hadari, H. M Martini, Insumen Penelitian Sosial 1992:70) Dalam hal ini, penulis melakukan observasi di Perpustakaan Desa Rende.

b. Wawancara

Menurut Drs. Mardalis dalam bukunya yang berjudul Metode Penelitian Suatu Pendekatan Proposal ialah

"Wawancara adalah teknik pengumpulan data yang digunakan penulis untuk mendapatkan keterangan-keterangan lisan melalui bercakap-cakap dan berhadapan muka dengan orang yang dapat memberikan keterangan pada $\mathrm{Si}$ peneliti". ( Mardalis, Metode Penelitian Suatu Pendekatan Proposal , 1995:64)

Dalam hal ini, Penulis melakukan wawancara terhadap pengelola Perpustakaan Desa Rende dan Para Pemustaka yang datang ke Perpusdes Rende.

\section{HASIL DAN PEMBAHASAN}

Perpustakaan Desa Rende pada pertengahan tahun 2013 diiberi hibah berupa sarana dari Dinas Kearsipan dan Perpustakaan (DISARPUS) Provinsi Jawa Barat, mulai dari buku-buku sebanyak 1000 buah, rak 1 buah, meja 1 buah, kursi 6 buah, lemari berkas 1 buah, lemari mading 1 buah, dan lemari buku 1 buah, dan diberi pelatihan juga untuk para pustakawan hanya saja saat itu pustakawan dipegang oleh Perangkat Desa, seiring dengan kesibukan tugas dari Desa yang semakin banyak sehingga ruangan Perpustakaan Desa setiap harinya tidak ada yang menjaga.

Pada akhir tahun 2013 ada pergantian Kepala Desa, karena khawatir buku-buku menghilang maka ruangan Perpusdes dipindah ke pojok belakang ruangan Desa. Pada saat itu Kepala DISARPUS Kabupaten Bandung Barat Mengundang rapat para Ketua Tim Penggerak Pemberdayaan Kesejahteraan Keluarga (TP.PKK) Desa yang mana dijabat oleh istri Kepala Desa untuk mengambil alih pengelolaan Perpusdes di seluruh Desa yang ada di Kabupaten Bandung Barat yang memang kondisinya semua terbengkalai karena pengelola atau perangkat Desa sudah banyak pekerjaan dari Desa, Kepala DISARPUS meminta Ketua TP. PKK Desa untuk memperdayakan kader PKK untuk menjadi relawan pengelola Perpustakaan Desa

DISARPUS tidak hanya menugaskan tapi juga memberi bimbingan teknis pada para relawan yang mau menjadi Pustakawan selama 6 hari untuk melayani para pemustaka nantinya, yang mana pada Disiplin Ilmu Perpustakaan seorang calon Pustakawan harus belajar selama 10 Semester atau 5 tahun untuk mendapatkan gelar Sarjana Perpustakaan. Berangkat dari pembekalan ilmu yang sederhana dan hanya mengandalkan semangat dan keinginan dari para relawan yang mau berpartisipasi maka saat itu juga Ketua TP.PKK Desa mulai memindahkan ruangan Perpustakaan Desa ke Aula yang letaknya ada di depan pintu masuk Desa dan ruangannya cukup luas, kebetulan di sisi kiri Desa adalah SD dan sisi kanan Desa adalah SMP maka pegunjung Perpus ramai hanya saja pengelola belum bisa menarik masyarakat umumnya dari beberpa kategori masyarakat seperti, Ibu-Ibu, para remaja, dan para Bapak-Bapak karena kurangnya minat baca atau masih takut datang ke perpustakaan Desa. 


\section{Kedudukan, Tugas dan Fungsi Perpustakan Desa Rende}

Kedudukan Perpustakaan Desa Rende

a. Perpustakaan Desa Rende adalah unsur pelaksanaan Pemerintah Kabupaten Bandung Barat di Dinas Kearsipan dan Perpustakaan

b. Perpustakaan Desa Dipimpin oleh seorang Sekretaris Desa yang berada di bawah dan bertanggung jawab kepada Kepala Desa

\section{Tugas Pokok Perpustakaan Desa}

a. Melaksanakan tugas dinas yang menjadi tanggung jawabnya sesuai dengan peraturan perundang-undangan yang berlaku

b. Melaksanakan tugas pembentukan yang diserahkan oleh Kepala Desa

\section{Fungsi Perpustakaan Desa Rende}

a. Melaksanakan kebijaksanaan teknis, memberikan bimbingan dan pembinaan sesuai dengan kebijaksanaan yang ditetapkan oleh Kepala desa berdasarkan perundangundangan yang berlaku

b. Melaksanakan kegiatan sesuai dengan tugasnya berdasarkan perundang-undangan yang berlaku

\section{Peranan Perpustakaan Desa Rende}

Kedudukan sebagai unsur kepemerintahan untuk menginovasi suatu perpustakaan Desa supaya lebih bisa dirasakan langsug manfaatnya khususnya untuk masyarakat Desa Rende, baik itu manfaat yang sifatnya langsung atau tidak langsung dapat diberikan kepada warga Desa Rende,

Manfaat yang sifatnya langsung seperti warga menjadi tahu dengan membaca akan sesuatu yang tadinya warga belum diketahui sedangkan manfaat yang sifatnya tidak langsung adalah hasil dari membaca menjadi sebuah impact yang bisa menaikan tingkat ekonomi masyarakat ataupun warga bisa menghindari sesuatu yang tidak diinginkan karena pengetahuannya bertambah atau bisa membentuk suatu karakter atau pribadi yang lebih baik karena impac dari membaca.

Tugas Pokok berpegang pada kebijakan Pemerintah Pusat sampai Pemerintah Desa, diantaranya Peraturan Menteri Desa No 3 tahun 2015 pasal 19 poin c) yang berbunyi : Pembangunan, pemanfaatan, dan pemeliharaan sarana dan prasarana pendidikan dan kebudayaan yang meliputi:

1. Taman Bacaan Masyarakat/PERPUSDES

2. Pendidikaan anak usia dini

3. Balai pelatihan/kegiatan belajar masyarakat

4. Pengembangan dan pembinaan sanggar seni

Sarana dan prasarana pendidikan dan pelatihan lainnya sesuai kondisi desa. Perpustakaan mempunyai peran yang sangat besar terhadap masa depan bangsa ini. Perpustakaan berusaha membantu masyarakat gemar membaca agar indonesia ini bisa mengikuti negara-negara lain yang sudah maju. kita semua mungkin prihatin melihat kenyataan bahwa masih banyak masyarakat kita yang buta huruf. Sungguh sangat disayangkan ternyata program pemerintah dibidang pendidikan belum berhasil. Masyarakat kota sudah mengenal kemajuan teknologi, namun jauh di sana masih 
banyak saudara kita yang buta huruf. Untuk sekolah dan mendapatkan buku saja mereka harus berjuang jauh. Sangat diharapkan bahwa kehadiran perpustakaan ini akan dapat membantu memecahkan masalah tersebut. Sehingga dapat memenuhi fungsinya dalam mencerdaskan kehidupan masyarakat. Peran pengelola, menjadi penting, karena pengelola dalam perannya sebagai manajer harus memiliki keterlibatan yang penuh dalam proses pengorganisasian masyarakat, sehingga mampu menumbuhkan kemandirian dalam kehidupan ekonomi maupun dalam perannya sebagai bagian dari masyarakat (Mulyono, 2018).

\section{KESIMPULAN DAN SARAN}

Perpustakaan mempunyai peran yang sangat besar terhadap masa depan bangsa ini. Perpustakaan berusaha membantu masyarakat gemar membaca agar indonesia ini bisa mengikuti negara-negara lain yang sudah maju. kita semua mungkin prihatin melihat kenyataan bahwa masih banyak masyarakat kita yang buta huruf. Sungguh sangat disayangkan ternyata program pemerintah dibidang pendidikan belum berhasil. Masyarakat kota sudah mengenal kemajuan teknologi, namun jauh di sana masih banyak saudara kita yang buta huruf. Untuk sekolah dan mendapatkan buku saja mereka harus berjuang jauh. Sangat diharapkan bahwa kehadiran perpustakaan ini akan dapat membantu memecahkan masalah tersebut. Sehingga dapat memenuhi fungsinya dalam mencerdaskan kehidupan masyarakat.

\section{DAFTAR PUSTAKA}

Nawawi, H. 1995. Metode Penelitian Sosial. Yogya: Gajah Mada University Perss.

Nazir, M. 1998. Metode Penelitian. Jakarta; Ghalia Indonesia

Mardalis. 1995. Metode Penelitian. Jakarta. Bumi Aksara.

Mulyono, D. 2018. THE STRATEGY OF MANAGERS IN MOVING BUSINESS LEARNING GROUP PROGRAM IN PKBM SRIKANDI CIMAHI CITY. Journal of Educational Experts (JEE), Vol. 1 (1), hal. 41-50.

Nawawi, Hadari dan M. Martini Hadari. 1992. Instrumen Penelitian Bidang Sosial. Yogyakarta: Gadjah Mada University Press 